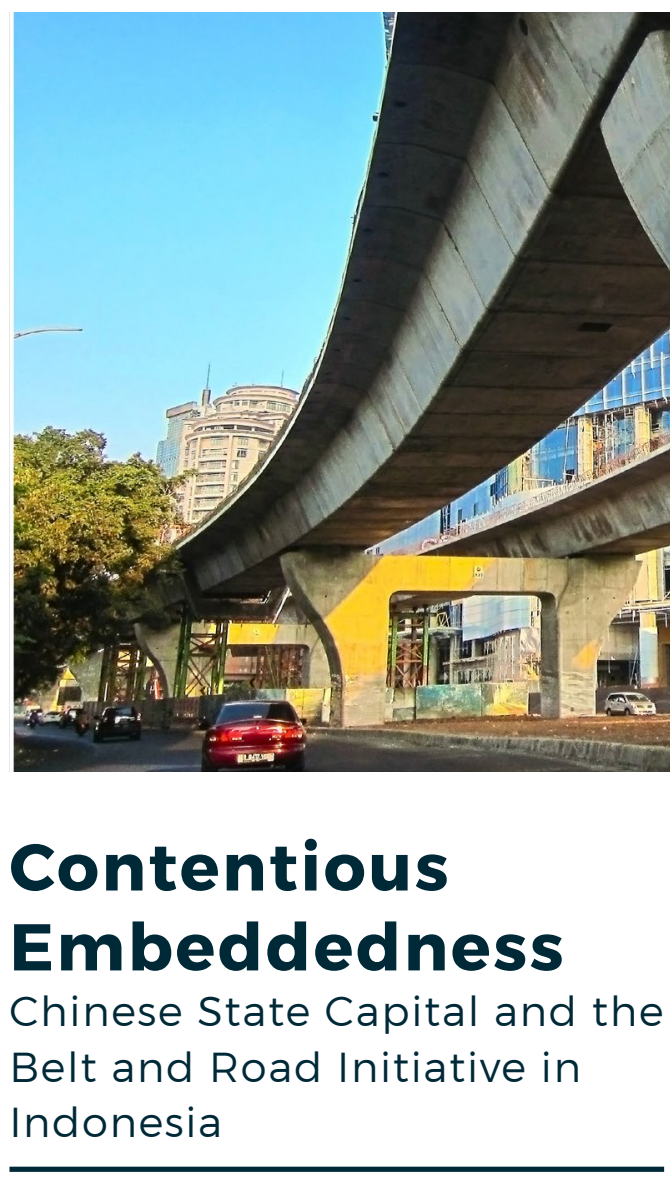

Angela TRITTO

This essay employs Polanyi's concept of 'embeddedness' to examine post-BRI Chinese investments in Indonesia. Using the case study of the Jakarta-Bandung high-speed railway, the article argues that key elements of this embeddedness can become active tools for policymakers to shape their strategy vis-àvis Chinese investments. In particular, in the Indonesian context such elements include the deep-rooted anti-China sentiment, populist and protectionist tendencies, and the well-established presence of Japanesecapital, inactive competition with Chinese capital for influence in the country. he launch of China's Twenty-first Century Maritime Silk Road in 2013 during a speech by President Xi at the Indonesian parliament is a testament to the fact that, as the largest economy in Southeast Asia, Indonesia holds a special status in China's ambitious Belt and Road Initiative (BRI). From the perspective of the BRI strategy, Indonesia not only has the potential to exert influence in the whole region, but it also constitutes one of the largest and most populous emerging markets with geographical proximity to China.

However, the relationship between China and Indonesia has been far from smooth. As pointed out by Chua (2008), 'Chineseness' in Indonesia is a purposively negatively 
stereotyped construct, built on the contested narrative that Chinese Indonesians' wealth makes up around 70 percent of the country's economy. In the past, this narrative allowed for a series of discriminatory policies against the Chinese Indonesian community, which has often become the target of pogroms, vandalism, and abuse, as it was blamed for political and economic crises: hence, the 'troubled relations' between the two countries (Sukma 1999). This sentiment is still strong nowadays and would seem to render the 'new' Chinese presence precarious.

\section{The Importance of Embeddedness}

In this context, the embeddedness of Chinese investments in Indonesia deserves attention. In Karl Polanyi's work (1944, 145), the concept of embeddedness encompasses three main considerations: a) markets are always and everywhere embedded, meaning that economic arrangements are constrained by intertwined economics, cultural, and political processes; b) markets at the national and global levels are shaped by an ongoing double movement in which the project by some sectors of society to expand the market always generates selfprotective movements by others to subordinate it; and c) political contestations occur at multiple levels: local, regional, national, and supranational, shaping the economic paths available to society at any given moment.

The contested embeddedness of Chinese investments in Indonesia has been well documented by previous scholars (Sukma 1999; Herlijanto 2018). This embeddedness includes four key elements: the 'troubled' past of foreign relations between China and Indonesia; the strong protectionist tendencies of the political and economic elite in Indonesia; the widespread anti-China sentiment across different levels of society; and the longstanding presence in Indonesia of Japanese companies and government agencies.
The serious local resistance to Chinese actors has shaped both the approach of President Widodo's government to his negotiations as part of China's BRI and the attitudes of Chinese leaders of business associations, which range from exasperation to acquiescence or even understanding. The country's long-standing protectionist tendencies expanded into some sectors, effectively forcing Chinese firms to establish joint ventures with local partners. Chinese companies have also been pressured into forms of regulatory compliance, which is at times unclear, arbitrary, or exploitable by corrupt officials. The developmental statecraft of Indonesian leaders has encouraged major Chinese investments out of mineral extraction and into mineral processing in an attempt to move up the value chain.

\section{Contentious Negotiations}

President Joko Widodo saw the BRI as an opportunity to bring much needed capital for infrastructure and industry development. Hence, using the political influence that Indonesia holds in the Southeast Asia region, along with the negative sentiment and countermobilisation against Chinese investment, the Indonesian government has been negotiating deals skewed in its favour (Tritto forthcoming). Much of this sentiment and countermobilisation, in part fuelled by social media, has revolved around questions of production and ethos (see Lee 2017). A centrepiece was the question of illegal Chinese workers entering Indonesia, with online rumours in 2019 alleging that this invisible contingent had already reached one million (Anwar 2019). Videos and news from the Indonesia Morowali Industrial Park, a Chineseinvested smelter plant, show incompatibility between the Chinese and the Indonesian ethos of production, as differential salaries, cultural and religious norms, and attitudes toward work gave rise to conflicts and protests (The 
Jakarta Post 2017a; The Jakarta Post 2017b). These frictions, however, led to not only an adjustment of the modes of production, but also to a series of official statements, inspections, and high-level directives for Chinese companies operating in Indonesia. One such example is the statement by Chinese Premier Li Keqiang during his official visit to Indonesia for the Indonesia China Business Summit. The declaration came after a wave of criticism against illegal Chinese workers in the country, which triggered a series of official inspections of Chinese industrial parks (Hermansyah 2017). Li exhorted Chinese companies to respect the law and hire Indonesian workers, but also urged the Indonesian government to reform the administrative process for investing in the country (Tempo 2018).

The presidential elections of 2019 were held against the backdrop of these contentious negotiations with Chinese capital. On that occasion, President Widodo faced a challenger who was the embodiment of Indonesia's populism and nationalism: Prabowo Subianto (Aspinall 2015). General Subianto, who later joined Widodo's cabinet as Defence Minister, built his latest campaign-as well as the previous one-on the claim that Indonesia's economic shortfalls were due to exploitation by foreign powers, particularly China. He led the initial counter-mobilisation against the Jakarta-Bandung HSR (Camba 2020). Had he been elected, the support for China's BRI in Indonesia would have certainly been imperilled.

\section{A Case Study in Contrast: Japan}

An important element of the contested embeddedness of Chinese capital in Indonesia is another, much more fluidly embedded, foreign capital: that of Japan. Investment from Japanese firms has been flowing into the country since the beginning of Soeharto's New Order in 1966, when the leader reshaped the FDI environment by re-establishing Indonesia's ties with the capitalist world economy (Lindblant 2015). Since then, Japanese investors in Indonesia have experienced quite a steep learning curve. Riots and protests such as the Malari incident in 1974, which saw students mobilise against pressures by Japanese competition to local businesses, led to protectionist reforms. This protectionism shaped Japanese capital until the 1990 s, when it evolved into the mix of official development assistance (ODA) tied to foreign direct investments (FDI) that is its defining feature today. Up to the 1990s, Indonesia had been the largest ODA recipient from Japan and, until this day, Japan maintains its primacy as the leading source of FDI in Indonesia (Wie 1994).

The long history of Japanese investments in Indonesia endowed Japanese companies, bureaucrats, and think tanks not only with strong ties to the local elites, but also with a specific knowledge of cultural and business norms. A series of interviews conducted between 2017 and 2019 with Indonesian business leaders and members of local organisations showed a strong favouritism towards doing business with Japanese companies, because the 'unfamiliar style and culture of Chinese business models made them less trustworthy'. In this often too generalised and stereotyped comparison, the interviewees also emphasised how the Chinese companies 'acted cocky and aggressively' and could mobilise capital and production at speeds that were impossible to achieve by compliance-bound Japanese companies. The example of the Jakarta-Bandung high-speed rail (HSR) project shows, however, that the renewed strength of diplomatic relations between China and Indonesia, as well as China's strong political will exerted through its state-linked actors have managed to overcome the contentious embeddedness of Chinese investments in Indonesia. 


\begin{tabular}{|c|c|c|}
\hline Parameter & $\begin{array}{l}\text { Chinese-Indonesian consortium } \\
(\mathrm{KCIC})\end{array}$ & Japanese consortium \\
\hline Project value & 5.13 billion USD & 6.2 billion USD \\
\hline $\begin{array}{l}\text { Government } \\
\text { commitment }\end{array}$ & $\begin{array}{l}\text { There is no government underwriting, } \\
\text { funding, or tariff subsidy } \\
\text { Cost overrun: KClC's responsibility }\end{array}$ & $\begin{array}{l}\text { Government underwriting is required, } \\
\text { funding from state's budget and tariff } \\
\text { subsidy } \\
\text { Cost overrun: government's responsibility }\end{array}$ \\
\hline Business concept & $\begin{array}{l}\text { The Joint Venture Company (i.e., } \mathrm{KCIC} \text { ) } \\
\text { is responsible for construction and } \\
\text { operations. Projects risk: } \mathrm{KCIC}\end{array}$ & $\begin{array}{l}\text { Engineering, Procurement, and } \\
\text { Construction, Financing (Regular } \\
\text { Contractor). Risk/liability: government }\end{array}$ \\
\hline Local content & 58,6 percent & 40 percent \\
\hline New jobs creation & $\begin{array}{l}\text { Construction period: } 39,000 \text { workers } \\
\text { per year. The Chinese workers } \\
\text { employed are limited to experts and } \\
\text { supervisors. }\end{array}$ & $\begin{array}{l}\text { Construction period: } 35,000 \text { workers per } \\
\text { year. Expatriates from Japan are required. }\end{array}$ \\
\hline Technology transfer & $\begin{array}{l}\text { Through the opening of rolling stock } \\
\text { factory in Indonesia. }\end{array}$ & $\begin{array}{l}\text { There was no tangible technology transfer } \\
\text { programme. }\end{array}$ \\
\hline
\end{tabular}

\section{The Case of the Jakarta- Bandung High-Speed Rail}

Plans to build an HSR in Java between Jakarta, Indonesia's capital city, and Bandung, the third largest city, had been floated even before 2010 (Barun 2010). Around September 2013, Japan made the first concrete proposals to sign an MOU with the Indonesian Ministry of Transportation for the construction of a Museum of Transport in Jakarta (Tempo 2013). At the time, the Japan International Cooperation Agency funded a first feasibility study to bring Shikansen trains to Indonesia
Table 1: Comparison between the Chinese and Japanese proposals to build the HSR. Source: Kereta Cepat Jakarta Bandung (The JakartaBandung High-speed Rail). March 2017. Informative booklet provided during interview with $\mathrm{KCIC}$.
(Parlina 2013). The feasibility study was ready in 2014, the year in which Joko Widodo became Indonesia's new president.

However, Japan's entreaties faced competition from China's ambitious connectivity plan to export its HSR technology through the BRI. After Joko Widodo's visit to China in March 2015, China and Indonesia signed a Joint Statement on Strengthening Comprehensive Strategic Partnership. This document included the 'MOU on Infrastructure and Industrial 


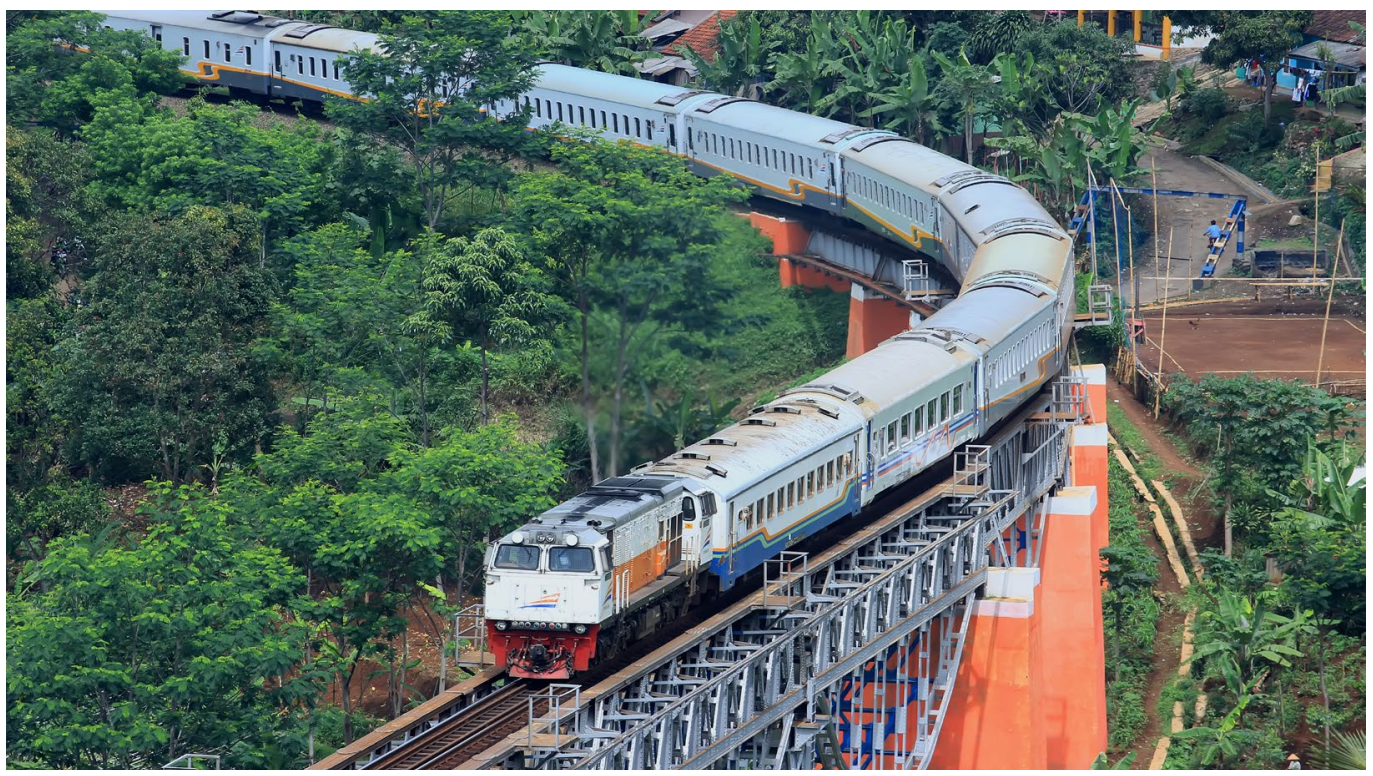

Jakarta-Bandung Railway. PC: @muhamadadlil,

Flickr.com.

Cooperation' and the 'Memorandum of Understanding on Cooperation on the JakartaBandung High Speed Rail Project' between the National Development and Reform Commission of the PRC and the Ministry of State-owned Enterprises of the Republic of Indonesia (Ministry of Foreign Affairs 2015). In April 2015, President Xi and President Widodo also inked a framework for the development of the 142-kilometre HSR (Wu and Chen 2015).

The months between April and September 2015 saw a heated competition between Japan and China to build this line. This competition involved negotiations between governments, whose projects called on policy banks and key national companies for their financing and implementation. In July, the Indonesian government organised a closed bid between the two countries to allow them to display their proposals, which local headlines referred to as a 'beauty contest' (Suroyo 2015). The Coordinating Minister of Maritime Affairs Luhut Panjaitan commented: 'Let them race to invest in Indonesia. It is good for us ... It is like a girl wanted by many guys; the girl then can pick whomever she likes' (Agence France Presse 2015). In September, the news reported that the Indonesian government had selected the proposal by China, but that shortly after had cancelled the whole plan because of technical and financial considerations (The Straits Times 2015). The Chinese government responded by offering a plan that required no government guarantees, which eventually gained favour in the Indonesian government. Table 1 summarises the conditions of the proposed Chinese and Japanese plans.

\section{High-speed Rail Diplomacy}

The Jakarta-Bandung HSR is emblematic of China's 'high-speed rail diplomacy' in Southeast Asia. Before this deal, China often offered to build HSR lines through Engineering Procurement and Construction 
(EPC) contracts, as in the case of the MalaysiaSingapore HSR, the Ankara-Istanbul HSR, or the Addis Ababa-Djibouti freight rail. However, in Indonesia a joint venture company named PT Kereta Cepat Indonesia China (KCIC), formed by a cluster of Indonesian and Chinese state-owned enterprises, is responsible for the construction and for at least 50 years of operating the line. The Pilar Sinergi BUMN Indonesia consortium (the Indonesian part of KCIC) holds a 60 percent stake in the joint venture and consists of four Indonesian state-owned companies that hold various mono or oligopolistic positions: Wijaya Karya (construction), Kereta Api Indonesia (railway), Jasa Marga (highways), and Perkebunan Nusantara VIII (agribusiness).

The consortium mode, along with the requirement for local materials to be used and for the employment of local labour, set a new precedent for other countries to imitate. For instance, after his election in 2018, Malaysian former Premier Mahathir successfully renegotiated the deal for the East Coal Rail Link to include better localisation and financing terms (The Star Online 2019). Similarly, after a round of renegotiations, the new Thai government adopted a consortium model led by the Thai CP Group (Reuters 2019). Most importantly, according to an interview with a leading scholar researching on China's export of HSR technology, 'The Indonesia HSR is a very symbolic but also very atypical project in the scenario of BRI HSR projects because it requires no government guarantees, which puts unwanted pressure on the China Development Bank.' Hence, the 4.5-billion-USD 40-year concessionary loan that covers 75 percent of the project cost signed between KCIC and the China Development Bank in May 2017 requires no guarantees from the Indonesian government (Reuters 2017).

Analysts and institutions like the OECD have commented on the implications that these loans may have on the stability of China's financial institutions and on the likelihood of their repayments (OECD 2018). A senior executive of Sinosure-a company that provided payment guarantees to projects like the rail line between Ethiopia and Djibouti, which lost 1 billion USD-was critical towards the project, saying it 'lacked adequate planning' ( $\mathrm{Ng} 2018$ ).

Hence, the above discussion shows a potential conflict between political and economic goals. In this case it would seem the Chinese government was intent on winning a strategic bid, and that the terms appealed to President Widodo, among other leaders, as it provided the possibility of a quickly-finished project on generous terms that could coincide with his re-election. If, on the one hand, this new consortium model between state-owned companies might constitute an innovative way to add new infrastructure in developing countries without tapping into state budgets, the time pressure exerted by political agendas could eventually result in less control over the financial and economic viability of project, which in turn could have societal and environmental implications.

The case of the Jakarta-Bandung HSR shows how China's BRI projects are shaped by their 'embeddedness' in a certain country. The improvement in foreign relations, the quintessentially protectionists tendencies in Indonesia, the high visibility of the project and, hence, its potential to shape public opinion-as well as the competition with Japan-are all factors that influenced the final outcome of the deal. These projects are not only embedded in the economic, cultural, and political processes of the host country, but are also embedded in a regional and international context, where information flows and affects negotiations in other countries. Contestations can come at multiple levels, but also from within certain organisations, because of the conflicts between political motivations and economic benefits, which can especially affect state capital. Overall, this case shows how embeddedness is not a static set of conditions upon which Chinese capital acts, but rather a dynamic set of processes that actively shape this contentious new flow of capital from China, as well as Indonesia's political, economic, and social environment. 
This text is taken from Made in China Journal: Volume 5, Issue 1, 2020, edited by Ivan Franceschini, Nicholas Loubere and Christian Sorace, published 2020 by ANU Press, The Australian National University, Canberra, Australia.

doi.org/10.22459/MIC.05.01.2020.24 